\title{
Study on the Design Art Education Talents Training Mode of Colleges of Science and Engineering under the Background of Internet +
}

\author{
DONG Haibin \\ Xi'an University of Technology \\ Xi'an, China
}

\begin{abstract}
With the advent of "Internet +", new opportunities and challenges are brought to the design art industry. Creative thinking should be cultivated in design art major in colleges of science and engineering, which should be either run through the whole process of teaching. While highlighting the teaching characteristics, it also takes full advantage of the crossdisciplinary basic theory of multi-crossed disciplines and comprehensive advantage complementary of science and engineering. School-enterprise cooperation talents training mode with the core of innovation and entrepreneurship has been adopted in the professional teaching. It is of use to unceasingly inquire into the teaching content and teaching method of talents training mode which meets the design art education of colleges of science and engineering. Strengthening the cultivation of "double-teacher" teachers and opening up new curriculum are also of use to meet the qualified designer who are needed in "Internet +" era.
\end{abstract}

Keywords - "Internet +"; design art education; innovation and entrepreneurship; humanities development

\section{INTRODUCTION}

The essential feature of the concept of "Internet + " is the full integration of all industries based on the internet platform. With the advent of "Internet +", innovative approaches has been provided for the update of all industries and new opportunities and challenges have been brought to the design art industry. Facing the future deep integration of information technology and traditional industries in "Internet + " era, either entrepreneurs or employees should adapt themselves to the development requirements on thinking mode and occupational orientation. As an important subject in "Internet + " era, art design major in colleges of science and engineering should keep in step with the era characteristic of "Internet + " in the development of course profession. The typical requirement of times of the trend of internet should be conformed in course profession educational concept and the cultivation of university students' innovation ability. And the technical innovation should be promoted. [1]For example, school-enterprise cooperation motivates arts and design students to establish more multiform possibilities in innovation and enterprise capability. In terms of professional collaboration direction, faculty structural modification and the cultivation the creative thinking modes, the characteristics with more specialty supporting in engineering colleges should be highlighted.
Based on the practical situation, different subjects and curriculum should be combined. And major project of art and design major should be combined with the technologies with future development, such as self-media, augmented reality, virtual reality and three dimensional printing. Thus the directivity of talent cultivation has been reinforced.

\section{BACKGRound AND CURRENT SituATION OF DESIGN AND ART EDUCATION IN "INTERNET +" ERA}

The coming of "Internet +" era is an important strength for the deep integration and development of internet and other industries. The digital design education we faced has failed to adjust many traditional teaching methods. How to handle the relation of tradition and innovation? In the new curriculum setting of architecture and landscape architecture discipline of some colleges and universities, the students are still drawing the traditional plaster models and apple. As a new established specialty in the high-platform of knowledge and education system, they are still teaching some knowledge has have little to do with architecture and landscape. This really should be reconsidered. Some colleges and universities advocate reform every day, but they don't know what "reform" is. It is conceivable that education reform is really difficult. Teachers are keys to teaching thought. Teachers' ideas and actions which are failed to keep up with the newest one cannot solve the innovation problem fundamentally, although their innovation can be reflected in presentation techniques. Therefore, teaching reform should be conducted step by step with the innovation ability and the cultivation of the creative thinking modes as the core.

In terms of faculty structure, most teachers of the colleges and universities are not "double-teacher" teachers at present, which has restrained the current education development. "Double-teacher" is a kind of special requirements for teachers in order to adjust to the modernization education, which requires teachers to possess the following two qualities and abilities: firstly, professional theory and teaching level; secondly, practical skills of engineering technology. No matter university students with master degree or PHD degree at abroad, they should work in the society for three or five years and then come back to universities for the employment for teaching assistant. They cannot stay at university after the fiveyear teaching assistant job, instead, they return to the society again and apply for the lecturer or associated professor after 
achieving some results. However, in the universities here, students are able to become teachers directly, and then they apply for teaching assistant, lecturer or associated professor. They have homogeneous knowledge structure, who are lacking of the innovation of practical skills. The teaching staff brings serious obstacle for students' knowledge input. Although some colleges and universities are practicing the reform and sending young teachers to enterprises to practice, the conditions and threshold they set are too high, and the quantity is hardly enough for the need of the current young teachers. Therefore, how to guide teachers to broaden their knowledge is the problem that desperately needs to be solved in design education in the "Internet +" era, which including the development of the "double-teacher" teachers.

Design and arts work is a work which needs the innovation. Not everyone is capable to do it, nor the people with less cultural accumulation. However, art students enrolled by most of the colleges and universities are not so good at cultural courses. There are few students come to learn art who truly love art. How to change students' idea through a kind of education under the universal "conditional" education? Letting them loving art and guiding them fully developing their own cultural quality are of importance.

\section{Cultivating Creative Thinking Should Be Threading THROUGH THE WhOLE EDUCATION OF THE DESIGN AND ART}

The design education which is advocated in "Internet + " era should regard creative thinking as the main body of the basic education and put aesthetics and skills into innovation, instead of laying the groundwork of aesthetics and skills first and then guiding students to cultivate the creative thinking. When teaching students knowledge, "thinking" education should be strengthened. Students should be told how to learn and what should they do in future. Teachers should inspire students with profound cultural knowledge and broaden their horizon, which are able to have a direct impact on their future learning beliefs. The development of internet has turned the design education which is a kind of technical and aesthetic education and with the "performance" putting first to the education of solving the skill and aesthetic problems through adopting creative thinking. Aesthetic education and skill training education should be put into the creative thinking education method. For example, in the basic teaching of lettering course, the original method is to ask students write down all the horizontal strokes and vertical strokes of all the characters, including the black draft. After all these have been done, the course has almost come to the end. Students have grasped how to write, but they do not know how to use them and when to use them. Nowadays, the typeface is appearing just by clicking the keyboard of the computer. The students do not need to concentrate their efforts in practicing calligraphy. More time are spending to teach students how to use the typefaces, such as where to use Song or Black. The key is to "use". The traditional basic education cannot meet the requirements of the designer. As for the students of design art major, basic education is neither isolate, nor simple aesthetic education or technical education. It should be connected with creative thinking. Besides representing image, creative thinking should be advocated. And the thinking mode of students should be guided. In terms of teaching, practical, applied and characterized teaching methods should be adopted based on the characteristics of design. The innovation of subject talent and employment competitiveness can be strengthened when it is combined with internet technology, as well as the new "internet" thinking has embedded in the deep research of the course profession. That is to say, as design art major, it should keep up with the change of the ages development. It is essential to reform the teaching content and methods in talent cultivation and integrate the era characteristic of "Internet +". Therefore, the perception, imagination, creativity and the capacity and quality of practical application of students can be enhanced.

"Design and art education" emphasizes the intercommunication and mutual combination of art and science. However, the relationship between them is always troubles modern design education. Li Zhengdao once pointed out: "The common ground for art and science is human creativity, with the universality of truth as their aim to be pursued. As two sides of a coin, it cannot be separated." [2] The technical requirements of modern design usually cannot coordinate with the requirements of the form aesthetic feeling of art. Thus some social contradictions and different ideas occurred naturally. No wonder the current society reflect that the students cultivated by colleges and universities are useless and their working abilities are not strong. Why? It is because that our teaching is hollow, which do not come to the point. Four aspects are lacked, such as the pertinence of teaching plan, the research of professional development, the research of teachers and the analysis of market. Thus the unscientific, unreasonable and unpractical teaching methods are caused. What do designers in internet era need? What kind of social role and responsibility should they undertake? How to serve the enterprises and clients? These are a series of practical problems to be solved. To solve the need of social service and applied industry and let designers to serve the market are essential. Serving the society requires the transformation from the current education to innovation education and creative thinking education, rather than the intrinsic technical education; in terms of the professional education, students should be integrated with the society, who should practice in society and the first line of design. Colleges and universities should free their minds and do not addict to the credential mania anymore. Teachers with social practice experience should be employed to giving lectures. Thus the students with working abilities who are needed by society can be cultivated.

\section{Design ARt EduCATION In SCIENCE AND TEChNOLOGY UNIVERSITIES SHOULD Highlight THEIR TEACHING CHARACTERISTICS}

Under the support of related disciplines, such as visual communication, fine arts, environmental art and animation, the development of design art discipline cannot be separated from the blending and cooperation with modern science and technology, especially in design and art discipline in science and technology universities. What they shared are not only the resources of laboratory, information and library of engineering colleges. What's more, it is the background information which is relying on the science and engineering technologies of universities. Grasping the forward looking of design art education has greater advantages in the eyes at art education 
form the aspect of improving the science and technology. Design and art education should adhere to the subjectival position and norm while in the interaction with other inartistic disciplines and become the carrier of persisting, presenting and carrying forward the contemporary society humanistic spirit. [3]

In the early days, deep-rooted concept has been instilled into Chinese art education. The essential distinction between artist and scientist is the contrast between sensibilities and rational thinking mode. It is believed that the understanding towards science and technology should be cultivated in the learning of science and engineering. There is no need to consider more about humanities and art. Similarly, mathematics has been given up in middle school while cultivating the artistic talents. In some art colleges, students with rational thinking and scientific foundation are even being despised. In today's development of internet, science and technology, the innocence can be clearly realized when reviewing the past educational concept. Wu Guanzhong holds that "the affinity between art and science is existed. However, it is unconscious." [4] The world famous painter DaVinci is a great scholar, who is a scientist giant, literary theorist, philosopher, poet, musician, engineer and inventor.

Design and art education in science and technology universities should follow the following principles: devoting to the overlapping and fusion of design art and science and technology; giving full play to the interdisciplinary basic theory of interdisciplinary and comprehensive complementary advantages of science and engineering and the teaching characteristics of applied research. Therefore, it can not only cultivate the designer and artist of animation, game, communication alternation design and new media art in information and culture industries, but also provide a new thought for re-examining the development direction of science and technology in Humanity level. [5]

\section{THE APPLICATION OF SCHOOL-ENTERPRISE}

\section{Cooperation Talents Training Mode With the Core of} INNOVATION AND ENTREPRENEURSHIP

With the implementation of internet innovation talent development strategic planning and the publication of the policy which encourages university students to cultivate their innovation and enterprise capability through combining with internet, various supports have been provided to students to cultivate their innovation ability and start their entrepreneurial activities, such as capital, space, policy and tax revenue, which has facilitated university students to realize their entrepreneurial dreams. Under the guide of relevant policies carried by our country, various colleges and universities have gradually realized the significance of the education of innovation and enterprise capability towards students. And they have started and paid attention to the cultivation of innovation and enterprise capability in daily teaching process.

As for design and art major in science and technology universities, school-enterprise cooperation is undoubtedly the most effective one in a series of training methods of innovation ability. The effective school-enterprise cooperation mode of integrating "the spirit of art and craft co-governance" with the talents innovation and exploration of design art students in science and technology universities and strengthen the art teaching effect and students' practice abilities are always the ways of reformation advocated by the College of Art and Design of Xi'an University of Technology. Based on this thought, each major have established several school-enterprise laboratories. The core task of laboratories is to use the resource integration of enterprises and schools and the after-class time of different majors to incubate the students' innovation and enterprise capability by adopting the mode of technology business incubator. Innovation team mode of instructor + enterprise mentors + student team has been formed in the laboratories. It is essential to promote teaching effect in the practice ability training and practice cooperation consciousness in the form of business management, as well as improve innovation ability in the inspiration of business and entrepreneurship. At present, several development fields have conducted the team practice, such as game design, UI design, virtual reality and self-media brand cultivation.

Therefore, for design art major, besides using the creative thinking teaching method, strengthening the integration of specialty courses and innovation and entrepreneurship practice from the aspect of technology integration and innovation is of importance. Besides "double-teacher" teachers, designers and practical artists who bear comprehensive qualities and are able to serve the internet era can also be cultivated.

\section{CONCLUSION}

As for cultivating the design art educational talents of colleges of science and engineering under the background of "Internet +", art and design major have the characteristics of innovation and entrepreneurship in industries. Therefore, the combination of production, learning and research in this industry is of great significance. The current basic education should be transformed into innovation education and creative thinking education, rather than the intrinsic technical education; in terms of the professional education, it should be integrated with the society and lead students to practice in society and the first line of design. The implementation plan of design art major of innovation and entrepreneurship with the cores of enterprise mentors, "double-teacher" teachers and students' team should be formed. Besides, complete management methods should also be established. And these methods should be verified in each major of design and art in colleges of science and engineering. Therefore, starting from the relatively limited practice foundation and further expanding the results, as well as exploring more effective training mode of internet + innovation and entrepreneurship are essential. These results should be solidified and compiled into management document or guiding books which can be popularized and implemented. Therefore, the results can be used and benefited even in other majors of art and have a better response to the guiding spirit of internet + education of innovation and entrepreneurship of college students in our country. Besides, it has also provided a new developing thought for the education talents training mode of design and art major in colleges of science and engineering. 


\section{REFERENCES}

[1] Li Jiannan. Innovation Exploration of Art Design Major in Higher Vocational College under the Background of "Internet +" [J]. Beauty \& Times, 2016(7):116(In Chinese)

[2] Yan Changyuan. The Result of Art and science [EB/OL]. 2007-0527/2007-7-5 http://www.ccdy.cn/pubnews. (In Chinese)
[3] Bao Lin. Establishing the Height of the Discipline Development [J], Qinghua Art, Beijing: Tsinghua University Press, 2006(3):47-50. (In Chinese)

[4] Wu Guanzhong. Art and Science are Integrating Deeply Here [EB/OL]. Tsinghua News Network, 2006-11-13/2007-7-5. (In Chinese)

[5] Fu Zhiyong. The Five Years Art and Science have Walked Together [EB/OL]. Tsinghua News Network, 2004-11-19/2007-7-5. (In Chinese) 